Five decades of dramatic changes in submerged vegetation in Lake Constance

Murphy, Fionn; Schmieder, Klaus; Båstrup-Spohr, Lars; Pedersen, Ole; SandJensen, Kaj

Published in:

Aquatic Botany

DOI:

10.1016/j.aquabot.2017.10.006

Publication date:

2018

Document version

Peer reviewed version

Citation for published version (APA):

Murphy, F., Schmieder, K., Båstrup-Spohr, L., Pedersen, O., \& SandJensen, K. (2018). Five decades of dramatic changes in submerged vegetation in Lake Constance. Aquatic Botany, 144, 31-37.

https://doi.org/10.1016/j.aquabot.2017.10.006 


\section{Accepted Manuscript}

Title: Five decades of dramatic changes in submerged vegetation in Lake Constance

Authors: Fionn Murphy, Klaus Schmieder, Lars

Baastrup-Spohr, Ole Pedersen, Kaj Sand-Jensen

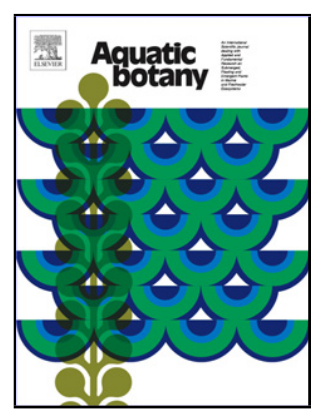

PII: $\quad$ S0304-3770(17)30306-6

DOI: $\quad$ https://doi.org/10.1016/j.aquabot.2017.10.006

Reference: $\quad$ AQBOT 2995

To appear in: $\quad$ Aquatic Botany

Received date: $\quad 1-9-2017$

Revised date: 26-9-2017

Accepted date: $\quad$ 19-10-2017

Please cite this article as: Murphy, Fionn, Schmieder, Klaus, BaastrupSpohr, Lars, Pedersen, Ole, Sand-Jensen, Kaj, Five decades of dramatic changes in submerged vegetation in Lake Constance.Aquatic Botany https://doi.org/10.1016/j.aquabot.2017.10.006

This is a PDF file of an unedited manuscript that has been accepted for publication. As a service to our customers we are providing this early version of the manuscript. The manuscript will undergo copyediting, typesetting, and review of the resulting proof before it is published in its final form. Please note that during the production process errors may be discovered which could affect the content, and all legal disclaimers that apply to the journal pertain. 


\title{
Five decades of dramatic changes in submerged vegetation in Lake Constance
}

Fionn Murphy ${ }^{\mathrm{a}, \mathrm{b}}$, Klaus Schmieder ${ }^{\mathrm{b}^{*},}$ Lars Baastrup-Spohr $^{\mathrm{a}}$, Ole Pedersen ${ }^{\mathrm{a}}$ and Kaj Sand-Jensen ${ }^{\mathrm{a}}$

${ }^{a}$ The Freshwater Biological Laboratory, University of Copenhagen, Unversitetsparken $4,3^{\text {rd }}$ floor, DK2100 Copenhagen, Denmark

${ }^{\mathrm{b}}$ Landscape Ecology and Vegetation Science, University of Hohenheim, August von Hartmann Str. 3, 70599 Stuttgart, Germany

*Corresponding author: Klaus Schmieder klaus.schmieder@uni-hohenheim.de

\section{Highlights}

- Lake Constance has continued to develop a more oligotrophic species composition

- Charophyte species richness and abundance have continued to greatly increase

- Changes appear most strongly related to dramatically reduced total phosphorus levels

- Recovery has occurred in a rapid and extensive fashion

\begin{abstract}
Lake Constance is the second largest lake in Europe. While naturally oligotrophic, the lake experienced a period of heavy eutrophication due to the input of domestic and industrial sewage and agricultural runoff in the 1960s and 1970s. This prompted concerted efforts from authorities to purify wastewaters and reduce agricultural nutrient input, initiating a phase of re-oligotrophication since the 1990s. Using environmental and submerged vegetation data from 1967 to 2016 , our objective was to analyse the temporal vegetation developments in the lake through the early periods of eutrophication and later periods of re-oligotrophication. Shifts in general vegetation functional groups and nutrientdependent macrophyte indices were compared with changes in water temperature, Secchi transparency and concentrations of total phosphorus and nitrogen. During the period of eutrophication, the lake was dominated by filamentous algae and tall, thin leaved macrophyte species. Upon reduction of lake phosphorus concentrations, from the 1990s onwards there was a rapid and marked increase in species richness, and charophytes emerged as the dominant species group. Charophytes showed a remarkable recovery from just two species in 1978 to ten species by 2016. These changes were primarily dictated by changing phosphorus concentrations that played a crucial role in interspecific competition. The close
\end{abstract}


link between macrophyte community composition and total phosphorus supports the conclusion that in the case of large naturally oligotrophic lake ecosystems such as Lake Constance, nutrient levels may be a much more informative metric for quantifying vegetation development than centralised Secchi transparency readings.

Keywords: aquatic macrophytes; phosphorus; eutrophication; re-oligotrophication; species recovery; long-term development; Lake Constance; charophytes

\section{Introduction}

In the early 1900s, accelerated wastewater production from increasing populations, industrial activity and fertiliser usage began to greatly alter the biological character of freshwater bodies in much of the Northern Hemisphere (Lachavanne et al., 1992; Sand-Jensen et al., 2000; Moss, 2009). Such wastewaters are rich in phosphorus (P) and nitrogen (N), nutrients which profoundly affect freshwater ecosystems (Elser et al., 2007), leading to dense phytoplankton blooms, turbid water and oxygen depletion in bottom waters (Correll, 1998). Different nutrient and light requirements between macrophyte species can greatly alter community composition in affected lakes (Schmieder, 1997; Vestergaard and Sand-Jensen, 2000; Hilt et al., 2006) and ultimately lead to loss of all submerged vegetation in hypertrophic lakes (Brodersen et al., 2001). In response to the observed loss of water quality and biodiversity, widespread efforts have been made in recent decades to improve and restore lake ecosystems previously damaged by nutrient pollution (Jeppesen et al., 2005; Baastrup-Spohr et al., 2016; Baastrup-Spohr et al., 2017; Sand-Jensen et al., 2017). This effort was primarily undertaken by the installation of advanced sewage treatment facilities alongside better handling of fertilisers and liquid manure in agriculture (Forsberg et al., 1975; Jeppesen et al., 2005)

Similar developments in nutrient input, water quality and submerged vegetation have occurred over the past century in Lake Constance. A large, naturally oligotrophic lake (maximum depth of $250 \mathrm{~m}$ ) situated on the northern fringe of the Alps, Lake Constance is the second largest lake in Europe by volume (Internationale Bodensee Konferenz [IBK], 2017) and acts as a vital water reservoir for over 5 million people (Petri, 2006). The lake forms part of the course of the river Rhine, which is responsible for 60\% of Lake Constance's overall annual water input (Güde and Straile, 2016). During a eutrophication process which peaked during the 1970s and 1980s, the region experienced 
large negative economic effects resulting from damage to tourism and fisheries industries (Lang, 1981; Schmieder and Kümmerlin, 1998). Prolific growth of phytoplankton and filamentous algae led to unfavourable conditions for bathing, while oxygen depletion arising from mineralization of algae caused the collapse of fish stocks (Global Nature Fund [GNF], 2017). Macrophyte species suited to low nutrient conditions, such as the once widespread charophytes, subsided massively, with only 2 of the 17 once-present species remaining by 1978 (Dienst et al., 2012). Certain waterfowl, dependent on these species as a food source, including ducks such as the Red-crested Pochard (Netta rufina) declined markedly (Schmieder et al., 2006). A combination of investment in improved regional wastewater treatment plants and the 1981 "Regulations on Maximum Concentration of Phosphorus in Detergents and Washing Agents" bill in Germany (GNF, 2017) led to a gradual improvement of conditions by the 1990s (Schmieder and Kümmerlin, 1998). However, no detailed full lake vegetation survey has been conducted since 1993, leaving an incomplete picture of how these early improvements have developed over recent decades.

While several studies have been carried out on lakes undergoing eutrophication and reoligotrophication processes, the majority have pertained to lake nutrients, water transparency, fish populations and shifts in phytoplankton (Jeppesen et al., 2005). In the few cases where studies did address long-term vegetation changes (e.g. Baastrup-Spohr et al., 2016; Sand-Jensen et al., 2017), large deep lakes have seldom been the focus of examination. This global lack of data on macrophyte recovery of deep lakes serves to reinforce the importance of continuing studies of Lake Constance.

It is assumed by European Union programmes such as the Water Framework Directive that community recovery can be directly achieved through the improvement of environmental conditions. However, existing studies on smaller lakes show that recovery from eutrophic conditions can take many decades, and that it may not be possible to fully restore the original species composition (Hilt et al., 2006; Sand-Jensen et al., 2017). Hindrances may be caused by the formation of unsuitable muddy sediment for root anchorage and proper function of macrophytes, high internal release of nutrients and phytotoxic substances from enriched sediments under reduced conditions (Schmieder, 1995), and loss of species from regional species pools (Sand-Jensen et al., 2008; Sand-Jensen et al., 2017). Previous studies of vegetation development in Lake Constance, which covered the period 1967-1993, suggested that macrophyte communities had recovered quickly and substantially since the eutrophication peak of the 1970s (Schmieder, 1997; Schmieder 
and Kümmerlin, 1998; Schmieder and Lehmann, 2004). These studies demonstrated a reemergence of many nutrient sensitive species that had been marginalised in the preceding decades. The large catchment area (greater area for species to recolonise from) and extensive depth (dampening the potential for internal nutrient loading) of Lake Constance suggest that it may have a greater recovery potential than many of the smaller and shallower lakes upon which existing literature is based. This possibility is further explored by the present examination of more recent submerged macrophyte community development in the lake.

By collecting and compiling recent vegetation data for Lake Constance together with existing historical records (1967-2016), this study aimed to evaluate temporal changes in macrophyte species richness and abundance in relation to shifting environmental conditions. Specifically, we hypothesized that: 1) the relative abundance and richness of charophytes have increased with the ongoing oligotrophication since 1993;2) macrophyte species as indicator groups for nutrient exposure (Melzer, 1988) have changed in accordance with shifts in lake nutrient levels, and 3) observed vegetation changes should be either strongly related to nutrient availability, water transparency, temperature fluctuations, or multiple of these conditions.

\section{Materials and Methods}

\subsection{Study Area}

Lake Constance forms part of the course of the River Rhine and is situated on the northern fringe of the Alps at an altitude of 395 meters. The lake's shores are divided between Germany, Switzerland and Austria. The lake comprises two basins, the large deep upper lake (Obersee) and the comparatively small and shallow lower lake (Untersee), both of which are connected by a narrow stretch of water. Lake Constance is very deep (254 m) and has a surface area of $536 \mathrm{~km}^{2}$ with a catchment area of 11,500 $\mathrm{km}^{2}$ (Internationale Gewässerschutzkommission für den Bodensee [IGKB], 2013). The lake is fed by 14 different tributaries, with the majority of the water volume entering the eastern part of the upper lake (Güde and Straile, 2016). Agriculture still represents the primary land use in the catchment with much land being used for pasture and fruit production (Hammerl and Gattenhoehner, 2004). Tourism is of major economic importance to the area with over 10 million annual overnight guests visiting the region, largely in the summer months (Hammerl and Gattenhoehner, 2004). 


\subsection{Environmental conditions}

Data on environmental variables were obtained from Landesanstalt für Umwelt, Messungen und Naturschutz Baden-Württemberg (LUBW) and IGKB. All environmental data were measured at the Fischbach-Uttwil recording station located centrally in the upper lake basin. Temperature records were available from 1965 until 2015. Annual averages were calculated based upon monthly temperature recordings at different depths between 0-10 $\mathrm{m}$. Secchi-depth readings were available from 1974 to 2015 . For most sampling years, one to two recordings were made every month. However, due to inconsistencies in recording, some years lacked data for all 12 months. These years were disregarded when analysing data. Annual averages for the summer growth months of May to September were used for each year where data were available. Total phosphorus recordings were available from 1964 onwards, while total nitrogen records existed from 1986 onwards.

\subsection{Macrophytes}

Vegetation data were collected in 2016 from Rohrspitz in Austria to Friedrichshafen in Germany, roughly $55 \mathrm{~km}$ of shoreline. This data were then combined with recent data from 6 smaller surveys, creating an account of vegetation patterns for the entirety of Lake Constance's shores for a period from 2009-2016 (hereafter to be referred to as 2016). This data were then compared to data of other existing full vegetation surveys from 1967, 1978 (Lang, 1981) and 1993 (Schmieder and Kümmerlin, 1998), resulting in a data set spanning almost 50 years.

\subsection{Field surveys}

The surveys in 2016 involved mapping of macrophyte communities in the littoral zone along the shoreline extending through Austria, Bavaria and Baden Württemberg. Field work was carried out between July and September in order to ensure species groups had fully emerged. Sampling procedures were undertaken in accordance with previous studies on the lake, first established in 1967 (Lang, 1981; Schmieder, 1998). Sampling was carried out from a boat using a weighted grapnel. Sampling points were taken approximately every $100 \mathrm{~m}$ following a zig zagging pattern to ensure inspection of a variety of depths between 1 and $15 \mathrm{~m}$. For each sample point, the location was recorded on a handheld Garmin GPS device (GPSMAP 62st). Upon dropping anchor, the grapnel was thrown from different sides of the boat 3-4 times, or exceeding that until no additional species were observed. Instances of specimens pulled up with the anchor were also recorded. This 
sampling was performed at a total of 497 sampling points across the study area. Where possible, species were identified and recorded on the boat; otherwise specimens were identified on land using identification keys (Moore, 1986; Preston, 1995) and expert consultation. The abundance of species at each sample point was recorded in accordance with previous studies. This was done using a scheme where estimated abundance of each recorded species was ranked on a scale of 1 to 5 (Kohler, 1978). These abundance estimations could then be used directly in later macrophyte index calculations.

The data collected in 2016 for this study were merged with the aforementioned smaller recent studies to create a single dataset for the whole lake using ArcGIS 10.3.1 (ESRI, Redlands, CA, USA). This 2016 layer could then be used for comparison with historic digital data from 1967, 1978 and 1993. One small inconsistency was presented by the fact that locations of recent data were recorded in point shape format whereas historic data (1967, 1978 and 1993) was in polygon shape format, mapped with the use of aerial photographs. As this study was not concerned with the spatial specificity of data, each individual polygon was treated as a single data point, making it comparable with the point data of 2016. The full data set includes the following number of data points (in parentheses) over the period: 1967 (1481), 1978 (1661), 1993 (2432) and 2016 (3231).

\subsection{Species richness}

Since species richness can be heavily dependent on sampling intensity (Gotelli and Colwell, 2011) combined with the uneven number of samples in the different surveyed years, we used coupled interpolation and extrapolation to obtain comparable estimates of species richness (Chao et al., 2014; Hsieh et al., 2016). Following the recommendations of Chao et al. (2014) we compared richness estimates at a common base number of samples of 3231. For each surveyed year, we thus calculated an estimated richness along with confidence limits as if we had collected the same number of samples in previous years as in 2016 following the calculation procedures in Hsieh et al. (2016). Further, the species accumulation curves allowed us to verify the validity of the observed species numbers from the estimate of sampling completeness. 


\subsection{Functional groups of macrophytes}

Vegetation data were divided into general functional groups with distinctions being made between tall elodeids (species growing $\geq 1 \mathrm{~m}$ ), small elodeids (species growing $<1 \mathrm{~m}$ ), floating-leaved species, mosses, charophytes and other macroalgae (see Supplementary Material 1). Their relative abundances were recorded based on species incidence data for each group. The changes in frequency of the nutrient sensitive charophytes were analysed based on individual species recordings using logistic regression (see data analyses). Furthermore, the species richness within each functional group through the surveyed years was calculated.

\subsection{Indices of macrophytes}

The macrophyte index (MI), a system developed for use in calcareous pre-Alpine lakes, was used to display the effects of nutrient exposure on the lake's plant communities (Melzer, 1988). These effects were quantified on a scale of 1-5 (5 indicating high, and 1 indicating low nutrient conditions). This index was the product of pre-determined indicator values based on species nutrient preferences (see Melzer, 1988) and recorded abundance as following:

$$
M I=\frac{\sum_{a-z} Q_{a-z} x I_{a-z}}{\sum_{a-z} Q_{a-z}}
$$

where $\boldsymbol{Q}_{\boldsymbol{a}-\boldsymbol{z}}=$ the cubed abundance rating of species a-z $\boldsymbol{I}_{\boldsymbol{a}-\boldsymbol{z}}=$ Indicator group of species a $-\mathrm{z}$ as outlined by Melzer (1988). Upon calculation of these index values, the averaged results per year and the changing distribution of value ranges were examined.

\subsection{Data analyses}

The temporal development in environmental variables was analysed using linear regression between yearly averages of individual variables as the dependent variable and year as the independent variable.

Changes in species richness were evaluated based on the richness estimates and their confidence limits based on the methodology of Hsieh et al. (2016).

Charophyte frequency was analysed using logistic regression of species recordings (charophyte $=1$, other macrophytes $=0$ ) as the dependent variable and survey year as the grouping variable. A Tukey post hoc test was used to test pairwise differences between surveyed years. 
The change in macrophyte index values across time was analysed using Kruskal-Wallis test followed by Dunn's post hoc test using sampling points as replicates.

Logistic regression was performed in R (R Core Team, 2016) while the remaining analyses along with all figures were made in GraphPad Prism (GraphPad Prism version 7.02, La Jolla, CA, USA).

\section{Results}

\subsection{Environmental conditions}

The main change in environmental conditions was dominated by phosphorus concentrations. Annual mean total phosphorus concentrations declined more than 10-fold and highly significantly (linear regression, $\mathrm{P}<0.001$ ) from about $90 \mu \mathrm{g} \mathrm{P} \mathrm{L}^{-1}$ in 1975 to only $7 \mu \mathrm{g} \mathrm{P} \mathrm{L}^{-1}$ in 2010-2015 (Fig. 1A). Also, annual mean total nitrogen concentrations declined significantly (linear regression, $\mathrm{P}<$ 0.001), though with small differences from about 985 to $932 \mu \mathrm{g} \mathrm{N} \mathrm{L}{ }^{-1}$ (Fig. 1B).

Although annual mean water temperature was not significantly linearly related to the investigated years (linear regression, $\mathrm{P}=0.26)$ a small increase $\left(1.0^{\circ} \mathrm{C}\right)$ was observed at macrophyte relevant depths of 10 meters to surface level over the 50 year period, with distinct minimum values in 1985 1995 (Fig. 1C). Mean summer Secchi depth declined significantly (linear regression, $\mathrm{P}<0.05$ ) during the entire period from about 5.4 to $4.1 \mathrm{~m}$ (Fig. 1D).

\subsection{Species richness and abundance of macrophyte types}

The recorded relative abundance of functional macrophyte groups and species richness changed markedly during the period of 50 years (Figs. 2A and 2B). To accommodate the potential effects of differences in sampling intensity, we estimated sample coverage along with species richness at a common base sample for all surveyed years (see Materials and Methods 2.5). Despite the differences in sampling intensity, the sample coverage was very high (>99\%) indicating that almost no species have been missed in the very intensive sampling. As a consequence of the high sample coverage, the richness estimates are very close to the observed values and showed a significant increase from 1978 to 1993 (Table 1), but no changes between the two early sample years (1967 and 1978) or the late sample years (1993 and 2016) based on the calculated 95\% confidence limits. 
Three charophyte species were present in 1967, and by 1978 only two species were left at a very low abundance (Figs. 2A and 2B). Subsequently, charophyte richness and their relative abundance increased to eight in 1993 and ten in 2016. Logistic regression of charophyte incidence showed that the survey year had a highly significant effect on charophyte frequency $(\mathrm{P}<0.0001)$. Post hoc analyses showed that all surveys differed significantly $(\mathrm{P}<0.0001)$ confirming the initial decrease in abundance between 1967 and 1978, along with the substantial increases afterwards (Fig. 2A). Eleven tall vascular macrophyte species accounted for $62 \%$ of the relative abundance in 1967 . By 1978, 12 tall species were present with a relative abundance of 61\%. In 1993, tall species richness reached 14, although relative abundance declined to $33 \%$. Subsequently, tall vascular macrophytes declined to 12 species and a relative abundance of $28 \%$ in 2016.

Six species of small vascular macrophytes accounted for $11 \%$ of relative abundance in 1967 . This decreased to $5 \%$ by 1978 with six species present. Subsequently, small vascular macrophytes increased to eight species in 1993 and 2016 and relative abundance first increased to $16 \%$ and then declined to $7 \%$.

Other macroalgae than charophytes included between two and five species which changed markedly during the period. Relative abundance peaked in 1978 (28\%) and then declined gradually in 1993 (15\%) and 2016 (4\%). Floating-leaved macrophytes had low species richness (two or three) and relative abundance (0.2-0.5\%) throughout the period. Likewise, species richness (one or two) and relative abundance (0.03-0.4\%) of aquatic mosses remained very low. See Supplementary Material 2 for individual species data.

\subsection{Index groups of macrophytes}

In 1967, the highest recorded relative abundance of species in index group 3 was (31\%) and in 4 (33\%) (Fig. 3). Group 2.5 was the next most prominent group (19\%). In 1978, relative abundance had increased in group 4 (46\%) and group 5 species (24\%), whereas abundance declined in group 2.5 (7.6\%) and 3 (14\%). During decreasing P concentrations after 1978, in 1993 and 2016, group 4 and 5 species declined substantially, whereas group 2.5 and 1.5 species gained dominance with relative abundances of $43 \%$ and $19 \%$, respectively in 2016 .

The average index values displayed the same temporal development with a significant increase between 1967 and 1978 (Kruskal Wallis, H=3424, $\mathrm{P}<0.0001$; Dunn's test, $\mathrm{P}<0.001$ ), followed by continuous significant decreases from 1978 over 1993 to 2016 (Dunn's, P<0.001). 


\section{Discussion}

Lake Constance is an outstanding example of a very large, deep lake successfully restored by reduction of phosphorus input through cross-border cooperation. Species richness and relative abundance of submerged macrophytes possessing different competitive and adaptive capabilities responded rapidly and markedly to changes in phosphorus concentrations over the 50 years of eutrophication and later re-oligotrophication. Our results are in contrast to the common assumption and findings that water transparency is the primary driver of macrophyte community composition. We first discuss changes in environmental conditions over the decades. Then we explore changes in functional groups of macrophytes. Finally, we evaluate interactions between environmental conditions and species groups and individual species with a focus on charophytes, which historically formed the very species-rich and dominant vegetation cover in the lake before nutrient enrichment took off.

Among all environmental variables, total phosphorus (TP) levels underwent by far the greatest changes in Lake Constance from when regular sampling began in 1964. Concentrations peaked in the late 1970s owing to the widespread input of untreated domestic sewage, P-rich detergents and fertilisers (Petri, 2006). Following efficient wastewater treatment and reduction of agricultural input, TP levels decreased 10-fold from the early 1980s to lower stable levels (ca. $7 \mu \mathrm{g} \mathrm{P} \mathrm{L}^{-1}$ ) in the

early 2000s. Historically, Lake Constance would have held TP concentrations of 3-4 $\mu \mathrm{g} \mathrm{L} \mathrm{L}^{-1}$ prior to anthropogenic influences (Kümmerlin, 2014) and, although contemporary phosphorus levels are low, they have not yet reached the very low levels of 100-150 years ago.

It is characteristic, given the large volume of Lake Constance and the decades of nutrient pollution, that reduced input rapidly resulted in 10-fold reductions of TP concentrations in Lake Constance compared to observations in other historical lake studies (Jeppesen et al., 2005; Schindler, 2012; Sand-Jensen et al., 2017). A major driving factor for this rapid decline of TP concentrations in Lake Constance is probably its great depth. While shallower lakes are more affected by internal Ploading from enriched sediments (Søndergaard et al., 2003), a portion of nutrients present will become effectively lost by sediment burial at great depths in deeper lakes such as Lake Constance. The wave action associated with such a large lake also has the potential to wash organic matter out of the littoral zone, thus decreasing their potential effects on species growth. Furthermore, due to the lake's low retention time of 4.3 years (Stich and Brinker, 2010), in-lake TP would be expected to be washed out within approximately 13 years (three retention times) upon the reduction of inputs 
(Jeppesen et al., 2005). Those conditions may account for the fast and pronounced recovery of Lake Constance compared with other lakes with longer retention times and shallower depths.

Total nitrogen concentrations changed only weakly, unlike that of TP. Unfortunately, data were not available prior to the 1980s making it unclear as to what extent agricultural intensification of the 1960s and 1970s in the drainage area affected in-lake concentrations. However, since nitrogen inputs are largely deposited from the atmosphere (Elser et al., 2009), this parameter is harder to control than TP. Similarly, water temperature did not change markedly over the timeframe of this study. Although some slight winter warming effects have been recorded (Straile et al., 2003; Fink et al., 2014), mean temperatures in the upper $10 \mathrm{~m}$ of the water column have not increased significantly over the 50 years.

Surprisingly, Secchi depth readings show no significant increase in water clarity throughout the reoligotrophication period in the lake after 1978. In fact, a decrease in water transparency is seen, starting from the late 1990s continuing through to 2016. However, a large variation is seen in recordings on a year to year basis. In many lake studies, water transparency is closely related to TP levels (Lambou et al., 1982). Hence, it is important to emphasize that Secchi depth in Lake Constance has not followed TP levels in their drastic decline since the late 1970s.

The lack of improved water clarity can be partially explained when accounting for some major recent flood events such as in 1999 and 2005 (Jöhnk et al., 2004; O'Leary and Wantzen, 2012), all likely being responsible for notable declines in recorded water transparency in those years. Frequent flooding can have sizable effects on lake water transparency (Squires et al., 2002). Levels of phytoplankton chlorophyll $a$ have decreased in conjunction with declining TP levels, resulting in more inter-seasonally uniform concentrations rather than high summer maxima (Stich and Brinker, 2010). However even at peak nutrient levels, chlorophyll $a$ concentrations remained quite low (Stich and Brinker, 2010), suggesting that other factors such as suspended material from tributaries may have outweighed nutrient effects on phytoplankton biomass and transparency (Jochimsen et al., 2014). This may explain why transparency has not followed changes in TP concentrations. Despite these decreases in water transparency, with many recent summer averages being lower than $4 \mathrm{~m}$, macrophytes have been recorded growing at depths reaching up to $10 \mathrm{~m}$. This suggests that transparency is higher in the littoral zones of Lake Constance than at its central measuring stations, 
possibly owing to the localised water clarification properties of submerged macrophytes (Scheffer, 1999).

The most notable changes in Lake Constance' species composition over the past 50 years has been the decline and later dramatic recovery of charophytes, a development that showed a strong negative relationship with TP concentrations. The first sample year (1967), when TP levels were elevated to 10 times the natural levels, was dominated by tall vascular elodeid species. These tall species are known to have a physiological and ecological advantage in elevated nutrient conditions by extending long shoots to the surface, often developing extensive canopies, to overcome high turbidity and outcompete smaller rooted species (Van der Bijl et al. 1989). The members of this plant group in Lake Constance came from a broad spectrum of nutrient tolerances, with Stuckenia pectinata (MI group 4) and Potamogeton perfoliatus (MI group 3) being the most prevalent. The success of the tall species likely caused shading on small charophyte and moss species (Sand-Jensen et al., 2017). This effect was particularly evident among the charophytes, which only included three species of very low abundance in 1967, in stark contrast to the 17 species recorded back in 1911 (Dienst et al., 2012).

Macrophyte index values suggested that plant communities in the 1978 sample year were by far the most nutrient affected. This year had peak levels of TP. The relative abundance of tall elodeid species remained constant from 1967 to 1978 . While some species within this group declined in abundance in 1978, highly nutrient-tolerant species such as S. pectinata and the large form of Zannichellia palustris (Melzer, 1988) showed large increases. Species within this group with lesser nutrient tolerances, particularly $P$. perfoliatus declined substantially within this period, offsetting expansions by other group members. This observed decline came at a time when "other macroalgae" (predominantly pollution-tolerant Cladophora sp.) expanded strongly. These macroalgae species are known to inhibit the growth of $P$. perfoliatus (Asaeda et al., 2004) and could have been a major factor in this decline. The observed proliferation of "other macroalgae" likely also contributed to the marked decline in relative abundance of charophytes. Another contributing factor was probably the huge increase in S. pectinata and Z. palustris abundance in this period. These species have been shown to shade macrophytes growing below, and may have contributed to the decline in charophyte abundance and the disappearance of Chara aspera (Van den Berg et al., 1998). The year 1978 marked the only time in the recorded history of Lake Constance when $Z$. 
palustris was widespread (Schmieder, 1997). Finally, the observed decrease in small elodeids likely resulted from the shading effects of the increased presence in taller and more nutrient tolerant species (Melzer, 1988).

The 1993 sample year displayed an increase in species richness, a decline in observed nutrient impacts on the submerged vegetation, as indicated by the macrophyte index, and an increase in species with lower nutrient tolerances, such as charophytes. This may have been facilitated by the high level of local and regional variation within the lake, providing different niches for recolonization upon the return to lower nutrient conditions (Schmieder and Lehmann, 2004). Furthermore, this re-emergence may be attributed to sprouting of oospores, which can remain viable in the sediment for numerous decades, an advantage charophytes have over other species groups (Krause, 1986; Hilt et al., 2006). Falling TP levels in this period corresponded with a marked shift in macrophyte index values towards nutrient poorer conditions. Large declines in previously dominant eutraphentic species such as Cladophora sp., S. pectinata, and Z. palustris led to decreases in the relative abundance of the two groups "other macroalgae" and tall elodeids. Perhaps most notable was the $46 \%$ decline in absolute numbers of recorded sample points of Cladophora sp. from 1978 to 1993. The reduced occurrence and shading from Cladophora sp. and the greatly reduced TP concentrations may have facilitated the large expansion of charophytes. More nutrient tolerant charophyte species such as Chara contraria, Nitellopsis obtusa and Chara globularis reemerged most strongly, similar to that seen in other restored deep lakes such as Lake Starnberg (Melzer, 1999). Chara aspera was again recorded for the first time since the 1960s in addition to five other charophyte species.

By 2016, although species richness did not notably increase, more characteristically oligotraphentic species greatly increased in abundance. Furthermore, two more charophyte species were recorded, and charophytes became the dominant functional group in Lake Constance, occupying $62 \%$ of overall relative abundance. Chara aspera, which is one of the most nutrient sensitive members of the group (MI group 1.5), displayed huge increases in abundance, becoming one of the most prominent species in the lake, second in abundance to $C$. contraria. This continued charophyte expansion again came at a time of greatly declining TP levels. Previously dominant eutraphentic species such as $S$. pectinata and the tall elodeids declined considerably at this time of reduced TP levels, a development that would have decreased shading effects on lower canopy species. 
Under suitable nutrient and light conditions, certain charophyte species are known to hinder the performance of tall macrophytes (Richter and Gross, 2013). Furthermore, the ability of charophytes to quickly utilise bicarbonate by acting as a nutrient sink, has been shown to inhibit S. pectinata growth and cause population declines (Hidding et al., 2010). Indicator values of the submerged vegetation for this recent period reflect the lower TP concentrations that had decreased considerably since 1978, and now depicted low nutrient effects.

Changes in vegetation dynamics appear to be most closely related to TP concentrations. The trends in average TN, temperature and Secchi depth have not developed in a manner that can account for macrophyte development in Lake Constance over the last 50 years. Differentiating periods of dominance between characteristically eutraphentic and oligotraphentic species coincide with temporally peaking and declining TP levels. This link is compounded by macrophyte index values, which show a similar trend. Our results are in contrast to the common assumption and findings that water transparency is the primary driver of macrophyte community composition (Middelboe and Markager, 1997). Our findings also support the notion that these developments in species composition are strongly influenced by interspecific competition relating to phosphorus availability.

Nonetheless, water transparency cannot be disregarded as a contributing factor to the observed macrophyte development. The huge and varied physical nature of Lake Constance means there is a potential for spatial variation in water transparency along the shoreline, something not accounted for by our mid-lake Secchi measurements. Readings taken from such mid-lake stations cannot fully account for the effects that macrophytes may have on water clarity in the littoral zone several kilometres away, for example, by enhancing particle sedimentation (Scheffer, 1999). Given the mean lake depth and good water exchange conditions between mid-lake and littoral stations, our data from mid-lake stations should still be a reliable proxy for the historical development of light conditions in the water column surrounding the submerged macrophytes in the littoral zone. The close link between macrophyte community composition and in-lake TP levels supports the conclusion that in the case of large naturally oligotrophic lake ecosystems, nutrient levels may be a much more informative metric for quantifying vegetation development than Secchi depth. Thus, macrophyte communities in lakes with similarly low baseline TP concentrations would likely be comparably sensitive to fluctuations in phosphorus levels. 


\section{Acknowledgements}

This project was funded by the University of Hohenheim, Germany, and University of Copenhagen, Denmark. Special thanks is extended to Michael Dienst, Irene Strang, Eva Boy, Mona Sanny, Markus Ulma, Jana Hohner, Magge Janke and Gunnar Franke who all contributed to the creation of this dataset. We are grateful to the LUWB and IGKB for sharing their long term environmental data which were so important to this study. 


\section{References}

Asaeda T., Sultana M., Manatunge J., Fujino T., 2004. The effect of epiphytic algae on the growth and production of Potamogeton perfoliatus L. in two light conditions. Environmental and Experimental Botany, 52, 225-238.

Brodersen K.P., Odgaard B.V., Vestergaard O., Anderson N.J., 2001. Chironomid stratigraphy in the shallow and eutrophic Lake Søbygaard, Denmark: chironomid-macrophyte co-occurrence. Freshwater Biology, 46, 253-267.

Baastrup-Spohr L., Kragh T., Petersen K., Moeslund B., Schou J.C., Sand-Jensen K., 2016. Remarkable richness of aquatic macrophytes in 3-years old re-established Lake Fil, Denmark. Ecological Engineering, 95, 375-383.

Baastrup-Spohr L., Sand-Jensen K., Olesen S.C.H., Bruun, H.H., 2017. Recovery of lake vegetation following reduced eutrophication and acidification. Freshwater Biology, DOI: 10.1111/fwb.13000

Chao A., Gotelli N.J., Hsieh T., Sander E.L., Ma K., Colwell R.K., Ellison A.M., 2014. Rarefaction and extrapolation with Hill numbers: a framework for sampling and estimation in species diversity studies. Ecological Monographs, 84, 45-67.

Correll D.L., 1998. The role of phosphorus in the eutrophication of receiving waters: a review. Journal of environmental quality, 27, 261-266.

Dienst M., Strang I., Schmieder K., 2012. Die Wasserpflanzen des Bodensee-Untersees im Wandel der letzten 100 Jahre. Mitteilungen der Thurgauischen Naturforschenden Gesellschaft, 66, 111-153.

Elser J.J., Andersen T., Baron J.S., Bergström A.-K., Jansson M., Kyle M., Nydick K.R., Steger L., Hessen D.O., 2009. Shifts in lake N: P stoichiometry and nutrient limitation driven by atmospheric nitrogen deposition. Science, 326, 835-837.

Elser J.J., Bracken M.E., Cleland E.E., Gruner D.S., Harpole W.S., Hillebrand H., Ngai J.T., Seabloom E.W., Shurin J.B., Smith J.E., 2007. Global analysis of nitrogen and phosphorus limitation of primary producers in freshwater, marine and terrestrial ecosystems. Ecology letters, 10, 1135-1142.

Fink G., Schmid M., Wahl B., Wolf T., Wüest A., 2014. Heat flux modifications related to climate-induced warming of large European lakes. Water Resources Research, 50, 2072-2085.

Forsberg C., Ryding S.-O., Claesson A., 1975. Recovery of polluted lakes. A Swedish research program on the effects of advanced waste water treatment and sewage diversion. Water Research, 9, 51-59.

Global Nature Fund (GNF), 2017. Success Stories at Lakes- Answer to the problem of Eutrophication at Lake Constance. [Online] Available at: http://www.globalnature.org/19077/Success-Lake-Constance1/02_vorlage.asp [Accessed 26/09/2017].

Gotelli N.J., Colwell R.K., 2011. Estimating species richness. In Margurran A.E., Mcgill, B.J. (Eds.), Biological diversity: frontiers in measurement and assessment, Oxford University Press, Oxford, pp. 39-54.

Güde H., Straile D., 2016. Bodensee: Ökologie und anthropogene Belastungen eines tiefen Voralpensees. Limnologie aktuell, 15, Schweizerbart, Stuttgart, $271 \mathrm{p..}$

Hammerl M., Gattenhoehner U., 2004. Lake Constance/Bodensee. Lake Constance Foundation. http://www.worldlakes.org/uploads/constance_30sep04.pdf , 1-29.

Hidding B., Brederveld R.J., Nolet B.A., 2010. How a bottom-dweller beats the canopy: inhibition of an aquatic weed (Potamogeton pectinatus) by macroalgae (Chara spp.). Freshwater Biology, 55, 17581768.

Hilt S., Gross E.M., Hupfer M., Morscheid H., Mählmann J., Melzer A., Poltz J., Sandrock S., Scharf E.-M., Schneider S., Van De Weyer K., 2006. Restoration of submerged vegetation in shallow eutrophic lakes - A guideline and state of the art in Germany. Limnologica - Ecology and Management of Inland Waters, 36, 155-171.

Hsieh T., Ma K., Chao A., 2016. iNEXT: an R package for rarefaction and extrapolation of species diversity (Hill numbers). Methods in Ecology and Evolution, 7, 1451-1456. 
Internationale Bodensee Konferenz (IBK), 2017. The International Lake Constance Region in Figures 2017. [Online] Available at: http://www.statistik-

bodensee.org/tl_files/statistik/downloads/publikationen/Die\%20internationale\%20Bodenseeregio n\%20in\%20Zahlen/Die\%2Ointernationale\%20Bodenseeregion\%20in\%20Zahlen\%202017/Bodensee Zahlen_2017_EN_1-Region.pdf [Accessed 26/07/2017].

Internationale Gewässerschutzkommission für den Bodensee (IGKB), 2013. Bodensee-Daten. [Online] Available at: http://www.igkb.org/der-bodensee/seedaten/ [Accessed 26/09/2017].

Jeppesen E., Søndergaard M., Jensen J.P., Havens K.E., Anneville O., Carvalho L., Coveney M.F., Deneke R., Dokulil M.T., Foy B.O.B., Gerdeaux D., Hampton S.E., Hilt S., Kangur K., Kohler J.a.N., Lammens E.H.H.R., Lauridsen T.L., Manca M., Miracle M.R., Moss B., Noges P., Persson G., Phillips G., Portielje R.O.B., Romo S., Schelske C.L., Straile D., Tatrai I., Willen E.V.A., Winder M., 2005. Lake responses to reduced nutrient loading - an analysis of contemporary long-term data from 35 case studies.

Freshwater Biology, 50, 1747-1771.

Jochimsen M.C., Kümmerlin R., Straile D., 2014. Phytoplanktonentwicklung im Bodensee von 1965 - 2007: Einfluss von trophischen und klimatischen Veränderungen. IKGB. Bericht Nr. 59

Jöhnk K.D., Straile D., Ostendorp W., 2004. Water level variability and trends in Lake Constance in the light of the 1999 centennial flood. Limnologica-Ecology and Management of Inland Waters, 34, 15-21.

Kohler A., 1978. Methoden der Kartierung von Flora und Vegetation von Süßwasserbiotopen. Landschaft und Stadt, 10, 73-85.

Krause W., 1986. Zur Bestimmungsmöglichkeit subfossiler Characeen-Oosporen an Beispielen aus Schweizer Seen. Vierteljahrsschrift der Naturforschenden Gesellschaft in Zürich, 141, 295-313.

Kümmerlin R., 2014. Der Bodensee-ein Überblick. Katalog des oberösterreichischen Landesmuseums, 163, 115-127.

Lachavanne J.-B., Perfetta J., Juge R., 1992. Influence of water eutrophication on the macrophytic vegetation of Lake Lugano. Aquatic Sciences, 54, 351-363.

Lambou V.W., Hern S.C., Taylor W.D., Williams L.R., 1982. Chlorophyll, phosphorus, Secchi disk, and trophic state. JAWRA Journal of the American Water Resources Association, 18, 807-813.

Lang G., 1981. Die submersen Makrophyten des Bodensees: 1978 im Vergleich mit 1967. Internationale Gewässerschutzkommission für den Bodensee, Bericht Nr. 26.

Melzer A., 1988. Die Gewässerbeurteilung bayerischer Seen mit Hilfe makrophytischer Wasserpflanzen. Hohenheimer Arbeiten-Gefährdung und Schutz von Gewässern. E. Ulmer, Stuttgart, 105-116.

Melzer A., 1999. Aquatic macrophytes as tools for lake management. Hydrobiologia, 395, 181-190.

Middelboe A.L., Markager S., 1997. Depth limits and minimum light requirements of freshwater macrophytes. Freshwater Biology, 37, 553-568.

Moore J.A., 1986. Charophytes of Great Britain and Ireland. Botanical Society of the British Isles.

Moss B.R., 2009. Ecology of fresh waters: man and medium, past to future. 3rd edition, Blackwell Publishing, Oxford.

O'Leary S.J., Wantzen K.M., 2012. Flood pulse effects on benthic invertebrate assemblages in the hypolacustric interstitial zone of Lake Constance. Annales de Limnologie- International Journal of Limnology, 48, 267-277.

Petri M., 2006. Water quality of Lake Constance. In: The Rhine. Knepper, T. P. (Ed.) Springer, Berlin, pp. 127138.

Preston C.D., 1995. Pondweeds of Great Britain and Ireland, Botanical Society of the British Isles.

R Core Team, 2016. R: A language and environment for statistical computing. R Foundation for Statistical Computing, Vienna, Austria. URL https://www.R-project.org/

Richter D., Gross E.M., 2013. Chara can outcompete Myriophyllum under low phosphorus supply. Aquatic Sciences, 75, 457-467.

Sand-Jensen K., Bruun H.H., Baastrup-Spohr L., 2017. Decade-long time delays in nutrient and plant species dynamics during eutrophication and re-oligotrophication of Lake Fure 1900-2015. Journal of Ecology, 105, 690-700. 
Sand-Jensen K., Pedersen N.L., Thorsgaard I., Moeslund B., Borum J., Brodersen K.P., 2008. 100 years of vegetation decline and recovery in Lake Fure, Denmark. Journal of Ecology, 96, 260-271.

Sand-Jensen K., Riis T., Vestergaard O., Larsen S.E., 2000. Macrophyte decline in Danish lakes and streams over the past 100 years. Journal of Ecology, 88, 1030-1040.

Scheffer M., 1999. The effect of aquatic vegetation on turbidity; how important are the filter feeders? Hydrobiologia, 409, 307-316.

Schindler D.W., 2012. The dilemma of controlling cultural eutrophication of lakes. Proceedings of the Royal Society B: Biological Sciences, 279, 4322-4333.

Schmieder K., 1995. Submersed macrophytes of two habitats in Lake Constance (Untersee) and their relations to chemical composition of surface and sediment interstitial water. Acta botanica gallica, $142,651-657$.

Schmieder K., 1997. Littoral zone-GIS of Lake Constance: a useful tool in lake monitoring and autecological studies with submersed macrophytes. Aquatic Botany, 58, 333-346.

Schmieder K., Kümmerlin R., 1998. Submerse Makrophyten der Litoralzone des Bodensees $1993 \mathrm{im}$ Vergleich mit 1978 und 1967, Internationale Gewässerschutzkommission für den Bodensee, Bericht Nr. 46.

Schmieder K., Lehmann A., 2004. A spatio-temporal framework for efficient inventories of natural resources: A case study with submersed macrophytes. Journal of Vegetation Science, 15, 807-816.

Schmieder K., Werner S., Bauer H.-G., 2006. Submersed macrophytes as a food source for wintering waterbirds at Lake Constance. Aquatic Botany, 84, 245-250.

Squires M., Lesack L., Huebert D. 2002. The influence of water transparency on the distribution and abundance of macrophytes among lakes of the Mackenzie Delta, Western Canadian Arctic. Freshwater Biology, 47, 2123-2135.

Stich H.B., Brinker A., 2010. Oligotrophication outweighs effects of global warming in a large, deep, stratified lake ecosystem. Global Change Biology, 16, 877-888.

Straile D., Jöhnk K., Henno R., 2003. Complex effects of winter warming on the physicochemical characteristics of a deep lake. Limnology and Oceanography, 48, 1432-1438.

Søndergaard M., Jensen J.P., Jeppesen E., 2003. Role of sediment and internal loading of phosphorus in shallow lakes. Hydrobiologia, 506, 135-145.

Van Den Berg M.S., Coops H., Simons J., De Keizer A., 1998. Competition between Chara aspera and Potamogeton pectinatus as a function of temperature and light. Aquatic Botany, 60, 241-250.

Vestergaard O., Sand-Jensen K., 2000. Alkalinity and trophic state regulate aquatic plant distribution in Danish lakes. Aquatic Botany, 67, 85-107.

Figure 1 

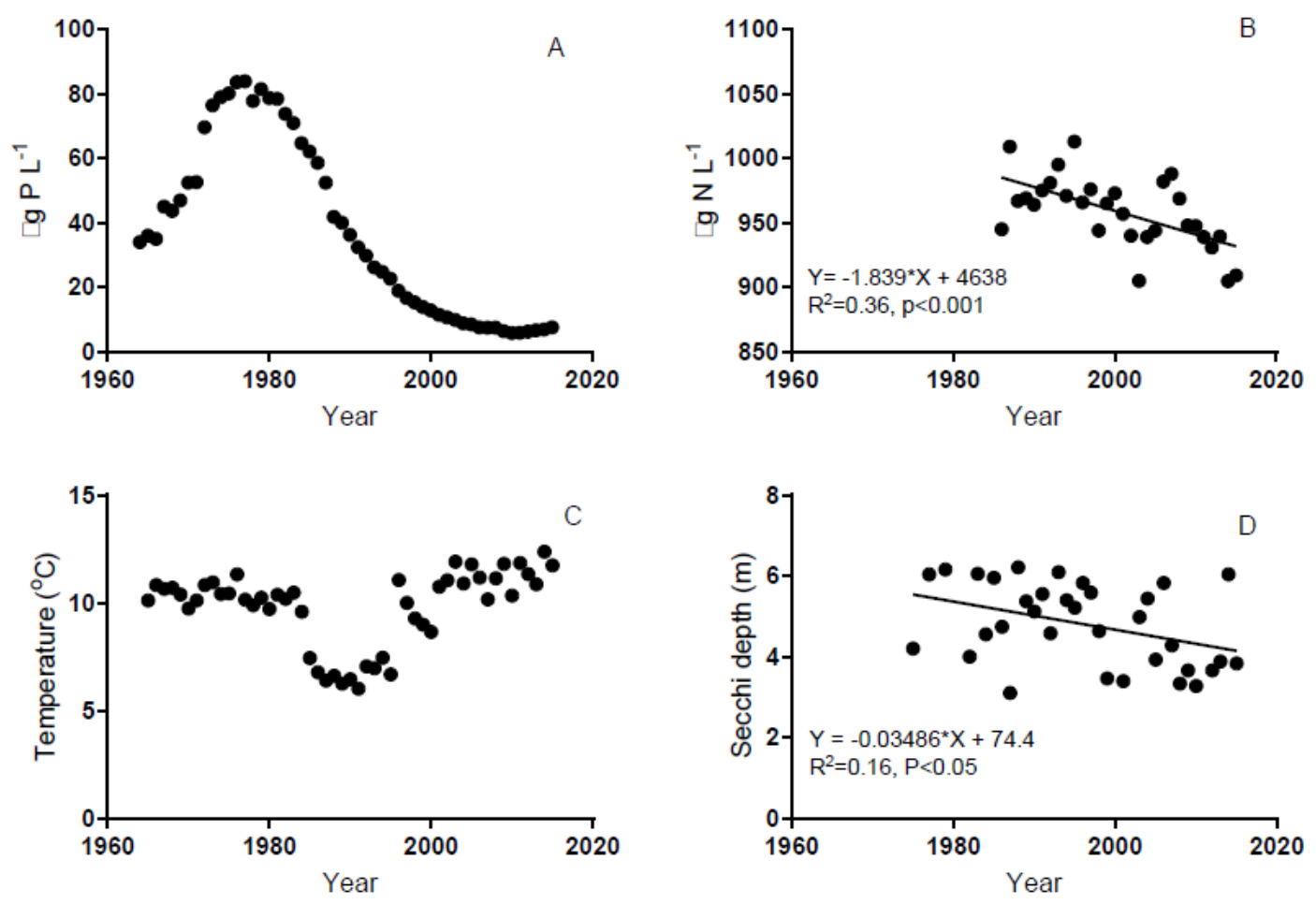
Figure 2
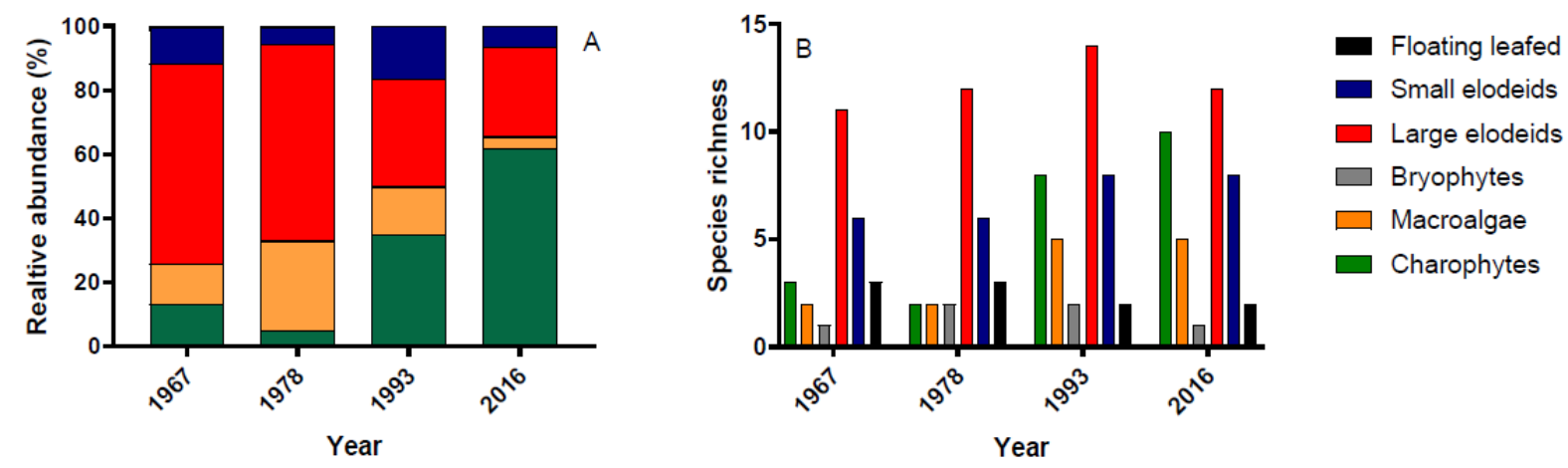
Figure 3
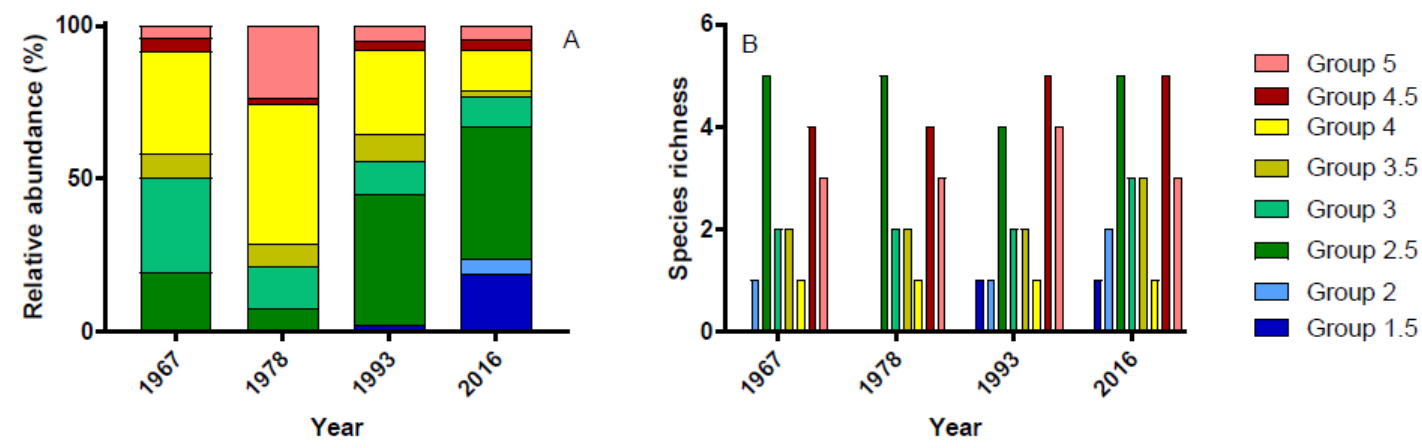
Tables.

Table 1: Species Richness Lake Constance. Observed and estimated species richness and confidence intervals using Chao et al. (2014)

\begin{tabular}{|c|c|c|}
\hline Sample Year & Observed Species & Estimated Species $( \pm$ C.I $)$ \\
\hline 1967 & 26 & $26.5 \pm 2.6$ \\
\hline 1978 & 27 & $28.2 \pm 3.3$ \\
\hline 1993 & 39 & $39.9 \pm 4.1$ \\
\hline 2016 & 38 & $38.0 \pm 1.9$ \\
\hline
\end{tabular}

